\title{
砂浜干潟併存場において前浜と干潟面を分ける 遷急線と汀線との斜交現象
}

\author{
橋本 佳樹 1 小林 昭男 $2 \cdot$ 宇多 高明 3 - 野志 保仁 4 \\ 1日本大学理工学部海洋建築工学科（干274-8501 千葉県船橋市習志野台7-24-1） \\ E-mail: csyo16019@nihon-u.ac.jp \\ 2正会員 日本大学教授理工学部海洋建築工学科（下274-8501 千葉県船橋市習志野台7-24-1） \\ E-mail: kobayashi.akio@nihon-u.ac.jp \\ 3正会員 一般財団法人土木研究センター常務理事なぎさ総合研究室長兼日本大学客員教授理工学部海洋 \\ 建築工学科（テ110-0016 東京都台東区台東1-6-4タカラビル） \\ 4正会員 日本大学助教理工学部海洋建築工学科（广274-8501 千葉県船橋市習志野台7-24-1）
}

\begin{abstract}
一般に，砂浜と干潟面とは遷急線で区分され，しばしば遷急線と汀線の斜交が起こるが，その形成機構は 不明であった。そこで砂浜と干潟が併存する館山湾に面した那古船形海岸において現地観測を行うととも に, 粒径を考慮した野志らのBGモデルを用いてその機構を調べた。この結果, 汀線と遷急線の斜交の原 因は，船形漁港の沖防波堤による波の遮蔽域内一と向かう沿岸漂砂の作用下で，汀線付近を集中的に移動 する粗な粒径成分の移動が突堤により阻止されたのに対し，細砂分は突堤沖を通過して遮蔽域内へと運び 込まれたことによることが分かった。
\end{abstract}

Key Words : break in slope, foreshore, tidal flat, Nako-funakata coast, field observation, $B G$ model, beach changes

\section{1. まえがき}

干潟は，河川や海食崖からの流入土砂が静穏な海域に 堆積して形成されるものであり, 海岸線沖に非常に広い 平坦面が形成されることで特徵付けられる.このような 干潟は, 多様な生物の棲息場, 産卵場として重要な役割 を果たしている．このため干潟には多くの関心が払われ， 生態学的研究も数多くなされている. これに対し, 干潟 の縁辺をな寸海浜の変化についての研究は十分ではない 宇多ら ${ }^{11}$ は，大分県の中津干潟にある三百間砂州の形成 と波浪による変形について現地観測により調べ，その中 で陸岸を構成する粗砂からなる海浜と干潟面とが，明瞭 な勾配変化点（遷急点）を持って互いに接していること

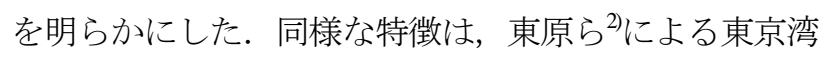
内の盤洲干潟の縁辺部での海浜変形の現地実測によって も観測されたし，宮原ら ${ }^{3)}$ も周防灘に面した干潟におい て遷急線がきれいに発達していることを明らかにした。 このように遷急点（線）は干潟と砂浜の境界に形成され るのであるが，実際にはその高さは空間分布を有し，そ れが波浪条件や底質粒度などと関係すると考えられるが, この点について論じた既往研究はない，そこで今回，砂 浜と干潟が併存する館山湾に面した那古船形海岸を調查
対象として現地観測を行うとともに，粒径を考慮した野 志ら゙のBGモデルを用いてその再現計算を行った.

\section{2. 現地観測の方法}

研究対象の那古船形海岸は, 図-1に示すように二級河 川平久里川河口の北側に伸びた長さ約 $1.5 \mathrm{~km}$ 砂浜海岸 である. 那古船形海岸の北端には船形漁港の防波堤があ り，さらにその沖には長さ300 mの沖防波堤が伸びてい る. 本研究では, 平久里川河口右岸側の護岸南端に基準 点を設け，この基準点から沿岸方向ほぼ北向きにX軸を， これと直角沖向きにY軸を定めた. 那古船形海岸では, 平久里川からの流出土砂が北向きの沿岸漂砂により運ば れ漁港周辺部に堆積している5。.このことから，2014年 11月までに $X=1 \mathrm{~km}$ において漁港方面への沿岸漂砂の低 減を図るために護岸から沖向きに長さ65 mの不透過突堤 が伸ばされた。

現地実測は2015年5月2日，7月30日，10月13日に行っ た。現地実測では汀線，遷急線，バーム頂を連ねる線を GPS（GARMIN社製のGPSmap 62scj，誤差はXY方向でさ3 m) 測量により定めた. 本論文での汀線とは, 調査日の 干潮時の水際線の位置のことである．また，遷急線とは， 


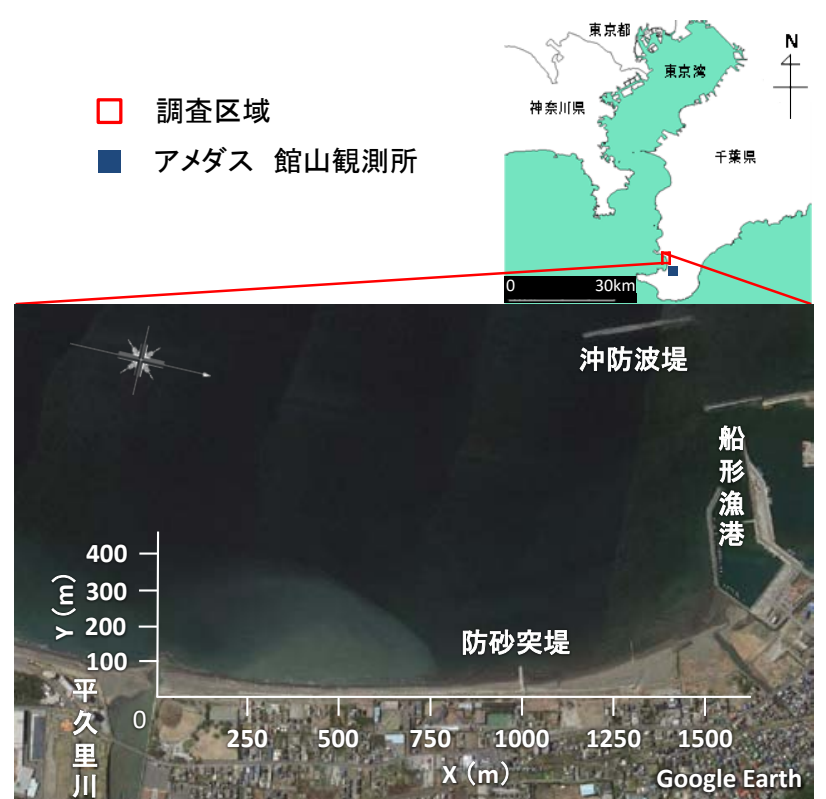

図-1＼cjkstart研究対象地の那古船形海岸と座標系

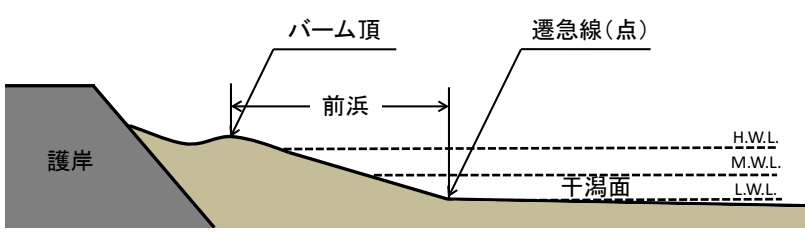

図-2 バーム頂と遷急線の定義

図-2の模式図に示すように，粗砂〜中砂からなる勾配 1/10程度の急勾配海浜と，その沖の $1 / 100$ 程度の緩勾配の 干潟面へと海底勾配が急変する地点を連ねる境界線のこ とを指す。本研究では，バーム頂と遷急線の間を前浜， 遷急線より沖を干潟面とした．遷急点の標高は2015年10 月13日に計測した，勾配については前浜と干潟面の勾配 両者を測定した．前浜と干潟面での勾配測定と底質採取 は，2015年5月2日に行った．図-3にはこれらの測点を示 す. 前浜構成材料の採取は測点1〜20で，干潟面での底 質採取は測点6’２0’で行った．採取した砂は乾燥後篩分 け分析を行って粒度組成を調べた。遷急点の高さは RTK-GPS（ニコン・トリンブル製のTrimble R4 GPS）を 用い，遷急線上を適当な間隔で行った.

\section{3. 那古船形海岸の潮位と気象条件}

那古船形海岸の潮位条件については, 当海岸が館山湾 内に位置していることから館山港での潮位を参照すると, HWLはT.P.+0.73 m，LWLはT.P.-0.85 mにある。また図-1 に示したように，那古船形海岸はほぼ西向きに開いてい るので，主として西側からの風波が卓越している，そこ で，アメダス館山を参照し，那古船形海岸における風向 の発生頻度を調べた（S〜Nへと時計回り）。気象観測 データとして，2010～2014年の風向別観測結果を用い， 四季ごとの風向出現頻度分布を図-4に示寸．図-4によれ

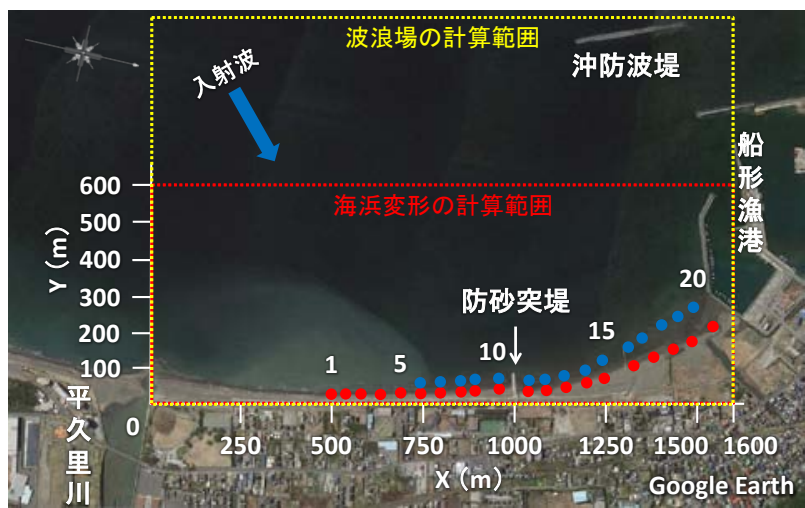

底質採取地点 (の前浜, ○潟面)

図-3 前浜と干潟面上での底質採取測点
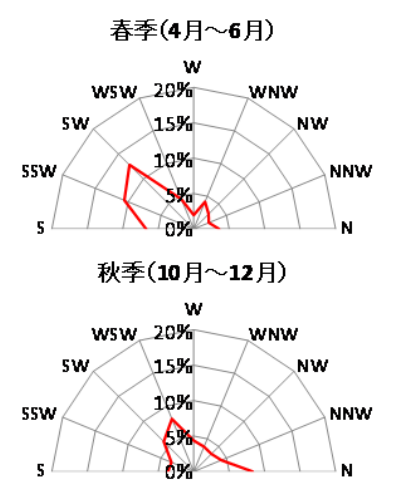

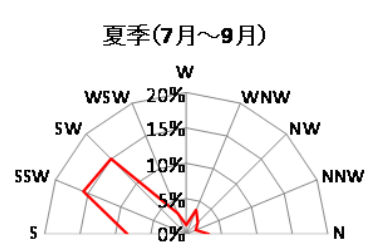

冬季 $(1$ 月 3月)

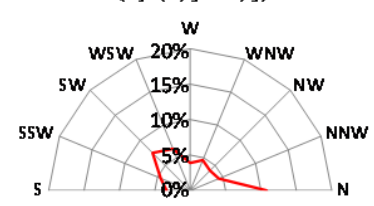

向（2010～2014年）
ば春季ではSWが12.8\%，SSWが10.5\%と卓越し，夏季で はSSWが15.7\%，SWが15 \%と高頻度である，一方，秋季 ではWSWが8\%，冬季はSWが7.5\%であり，全年で見る とSWが卓越している.このことから那古船形海岸での 卓越入射波向は，ほぼSW方向で与えられる.

\section{4. 現地観測の結果}

\section{(1) 現地状況}

2015年4月18日，那古船形海岸にある防砂突堤周辺の 海浜状況を調べた．防砂突堤は護岸から 65 m沖まで伸ば されており捨石製である。防砂突堤を北側から望むと， 図-5に示すように勾配 $1 / 10$ 程度と，急な前浜と沖合の干 潟面とが遷急線によりきれいに区分されていた，突堤上 から南向きに海浜を望んだ写真を図ー6に示寸が，陸側に は遷急線が伸び，その沖では干潮時汀線まで緩勾配の海 底面が続いていた．また，遷急線と干潮時汀線の間の平 たん面の幅は南向きに大きく狭まっていた，一方，同じ 場所の陸側では，図-7に示すように，バームが連続的に 発達していたことから, バーム頂を連祆る線の形状およ びバーム高の測定を行った.

（2）干潮時汀線，遷急線，バーム頂を連ねる線の形状

図-8には2015年5月2日，7月30日，10月13日の測量で得 られた干潮時汀線, 遷急線およびバーム頂を連ねる線の 


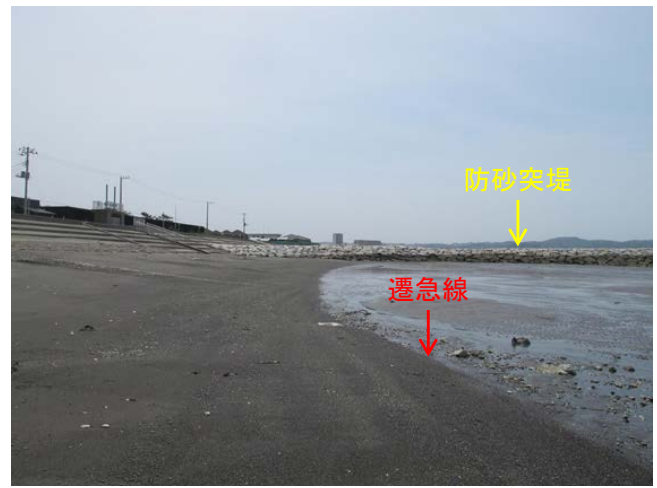

図-5＼cjkstart防砂突堤北側での遷急線

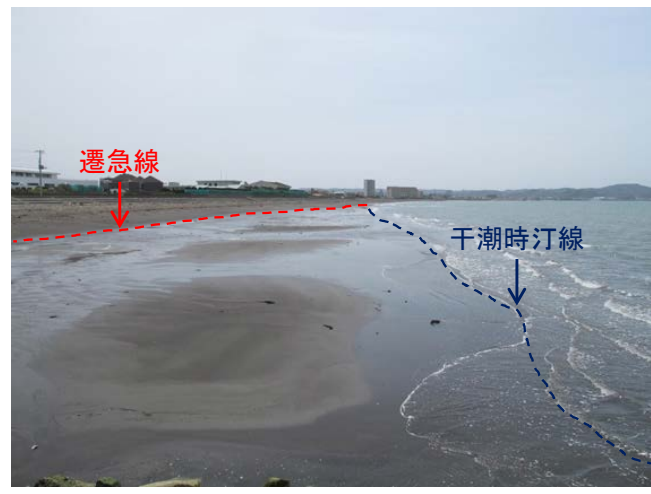

図-6防砂突堤の南側に伸びた遷急線と干潮時汀線

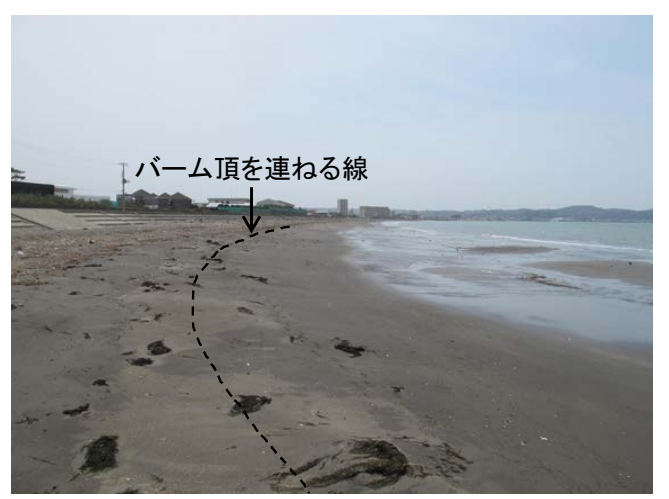

図-7＼cjkstart防砂突堤の南側でのバーム頂を連福る線の分布

沿岸分布を示す，遷急線はバーム頂を連ねる線とほぼ平 行に伸びているが，干潮時汀線は遷急線と平行ではなく 遷急線と汀線の間隔が平久里川河口から北向きに広がり を示し，遷急線〜バーム頂の急斜面の沖に広がる干潟面 では，平坦面の幅が北側ほど広いことが分かる．また， 潮位がT.P.-0.42 m時の干潮時汀線は防砂突堤を境に段差 ができており，北側で後退していることから，この水深 を通過する沿岸漂砂は突堤による漂砂阻止の影響を受け ているが，潮位がT.P.-0.77 mまたはT.P.-0.83 m時の干潮時 汀線は突堤を挟んでほぼ連続的に伸びていることから， 突堤の先端水深がほぼT.P.-0.8mにあることが分かる.

\section{(3) 遷急線とバーム頂の標高}

遷急点とバーム頂の標高の計測結果を図-9に示す。こ こにバーム頂の標高は，遷急点の標高，前浜勾配，前浜

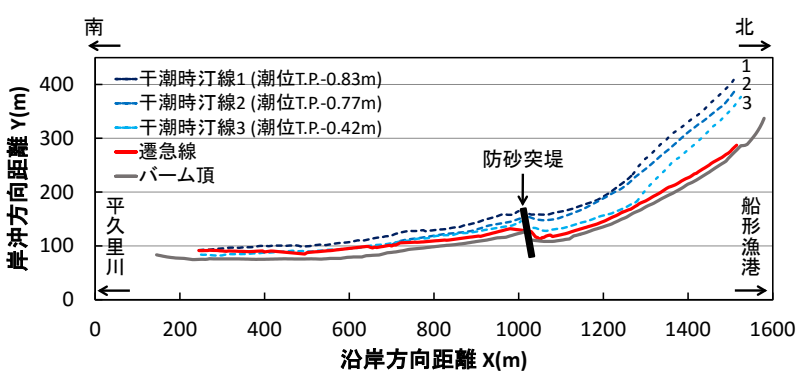

図-8 バーム頂を連ねる線，遷急線および干潮時汀線

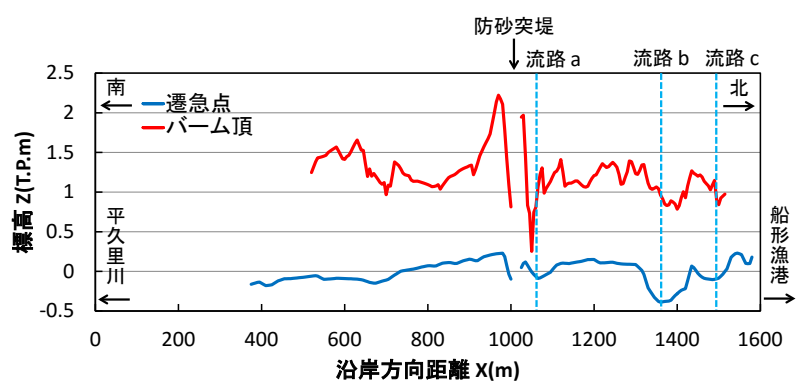

図-9＼cjkstart遷急線とバーム頂の標高分布

幅より逆算して定めた．バーム頂の標高は，突堤近傍で は乱れが大きいので突堤南側のごく近傍を除くと，X= 830 mから突堤へと急激に高まるが，突堤北側では平均 $1.1 \mathrm{~m}$ 程度の值を中心に変動しており, 平久里川から船 形漁港へと北向きに低下傾向を示した。 これは沖防波堤 による波の遮蔽効果に起因し，北部での波高低下に対応 していると考えられる. 一方，遷急点の標高は南部から 突堤へと増加傾向を示寸ものの，突堤北側の排水路から の流路a， b， cでは局所的に低い值を有している，とく に流路bでは標高が低い．このように遷急点の標高が低 下した理由は，これらの地点では排水路からの流水の作 用があり，沖向きの砂移動が起きたためと考えられる.

\section{(4) 前浜幅と干潟面の幅}

図-10には2015年7月30日の観測で得られた前浜幅と干 潟面の幅を示す。ここに，前浜幅はバーム頂から遷急線 までの距離，干潟面幅は遷急線から干潮時汀線までの沖 向き距離と定義した（図-2参照）。前浜幅は，平久里川 から船形漁港までほぼ12 mと一定であるのに対し，干潟 面の幅は平久里川から船形漁港方面へと北向きに急激に 増加し, 船形漁港に隣接する $X=1,515 \mathrm{~m}$ では $130 \mathrm{~m}$ で大 きく広がっている.

\section{（5）前浜勾配，干潟面の勾配および粒度組成}

図-11には前浜勾配と干潟面の勾配の沿岸分布を示寸。 前浜勾配は突堤南側直近の測点7 10では急激に増加す

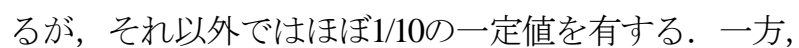
干潟面の勾配は，突堤南側では1/50であるが，突堤北側 では1/100 と, 約2倍まで勾配が緩くなり船形漁港側では 沖合まで緩勾配の干潟となっていることが分かる。一般 


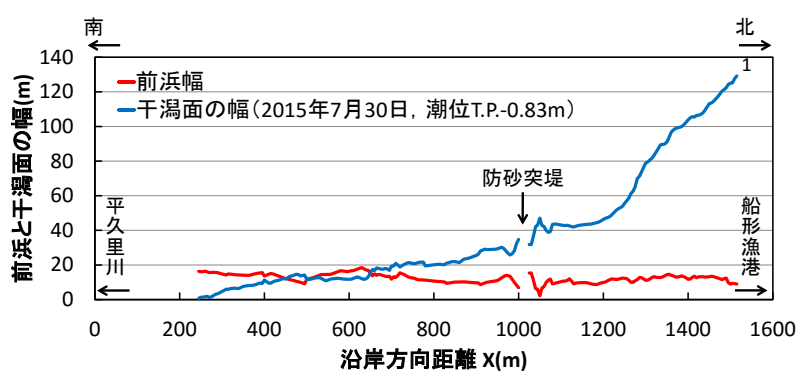

図-10 前浜幅と干潟面の幅の沿岸分布

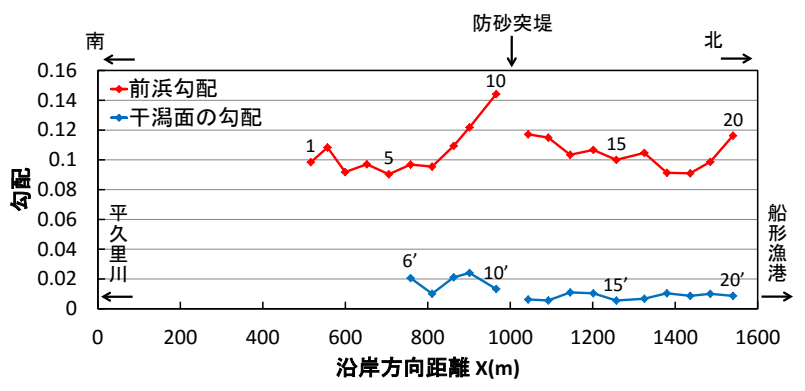

図-11 前浜勾配と干潟面勾配の沿岸分布

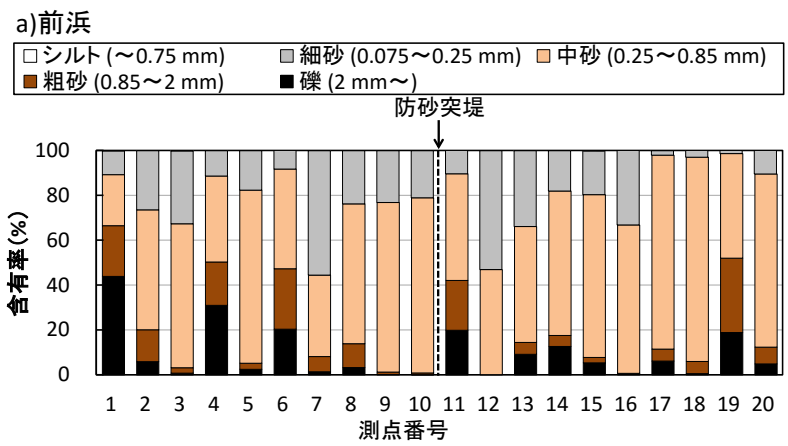

b)干潟面

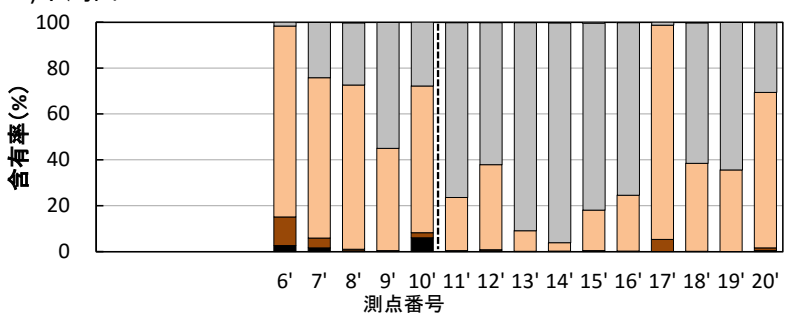

図-12 前浜と干潟面での底質粒度組成

的な泥質干潟の干潟面の平均勾配はほぼ1/1000であるのの に対し, 当海岸では1/50から1/100と勾配が急である.

図-12には前浜と干潟面での底質粒度組成の沿岸分布 を示寸. 前浜の粒度組成では, 突堤の両側で粒度組成に 大きな差は見られず，いずれの測線も中砂が約 $50 \%$ 占 め，それに細砂や粗砂が混ざった底質である，一方，干 潟面の粒度組成は，突堤の南側では測点6?で中砂が $80 \%$ 以上を占めているが，測点7， 8， 9'と突堤に接近する と中砂が45\%まで減少し，逆に細砂が55\%まで増加して いる. 突堤北側では, 細砂が60\%以上の測点が大半を占 める. また, 測点17’では河川が流入しているため中 砂の含有率が $90 \%$ と局所的に高まっている. いま突堤の 北側区域での底質含有率に着目すると，前浜では中砂以 上の粒径成分がほぼ75\%を占め, 細砂成分は25\%以下で

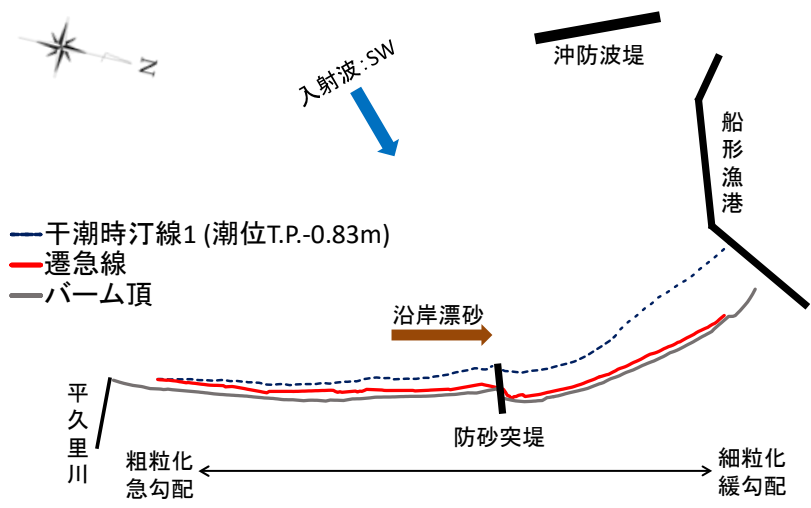

図-13 那古船形海岸の海浜変形の模式図

ある. 干潮上ではこれとちょうど逆転し，細砂が75\%， 中砂以上の成分がほぼ25\%を占める.

\section{BGモデルによる遷急線と汀線との斜交現象の 再現}

図-13の模式図を基に汀線と遷急線が斜交する理由に ついて考察すると，まず当海岸では沖防波堤による波の 遮蔽域が形成され，波の遮蔽域外の平久里川河口方面か ら北向きの沿岸漂砂が誘起されることが挙げられる. そ の際，相対的に粒径の大きな砂分は汀線付近に集中的に 堆積しつつ北向きに運ばれるが，そこに防砂突堤が伸ば されているためこれにより沿岸漂砂が阻止される.これ に対し，細砂成分は緩勾配で堆積しつつ北向きに運ばれ， その際, 漂砂带の幅が広いので防砂突堤による漂砂阻止 の影響が小さく, 細粒分は防砂突堤の先端を北側へと通 過することが可能となる.このようにして北向きの沿岸 漂砂により細砂が選択的に運び去られた結果, 平久里川 方面では干潟面の底質粒度が粗粒化する一方，北側では 細粒分が選択的に堆積したと考えられる. 以下ではこの 推定の妥当性をBGモデルを用いて検証した. なお, 那 古船形海岸での実測データ（図-12）に示すように, 前 浜と干潟面がそれぞれ卓越粒径で構成されていることか ら，2粒径での計算を行うが，その際の粒度は実測結果 （図-12）に基づいて， $d=0.3 \mathrm{~mm}$ (平衡勾配1/10）の中 砂と, $d=0.1 \mathrm{~mm}$ (同1/100) の細砂加らるとし, それ ぞれの含有率が $25 \%, 75 \%$ の混合砂を考え, それが分級 しつつ移動して図-12の粒度組成分布となったと考える. このような混合粒径砂からなる一様勾配海浜に波が作用 すると, 粒径に依存して平衡勾配が大きく異なることか ら, 中砂は岸側へ, 細砂は沖向きに急速に運ばれ, 前浜 と沖浜が遷急点で区分される縦断形となって安定化する. そこで初期形状として, 砂浜が+1.5〜-2 m間に分布し, その間の勾配が1/50の一様勾配海浜（図-14）をまず設定 し，この海浜に波高0.5mの波を十分長い時間（10日間） 作用させて安定形を求めた。 なお，図-14では勾配1/50の 斜面が- $2 \mathrm{~m}$ となる地点より沖は平坦面（固定床）とする 


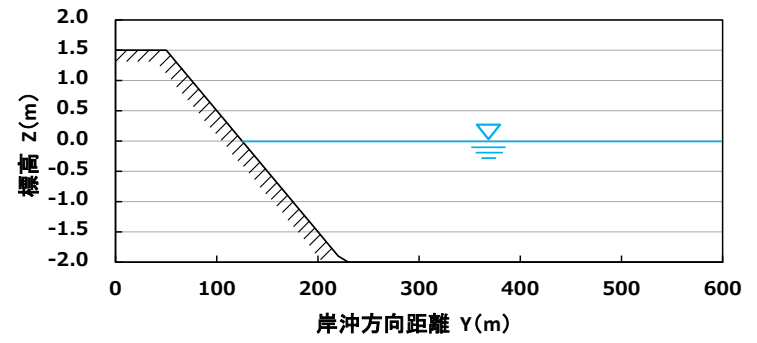

図-14 初期縦断形
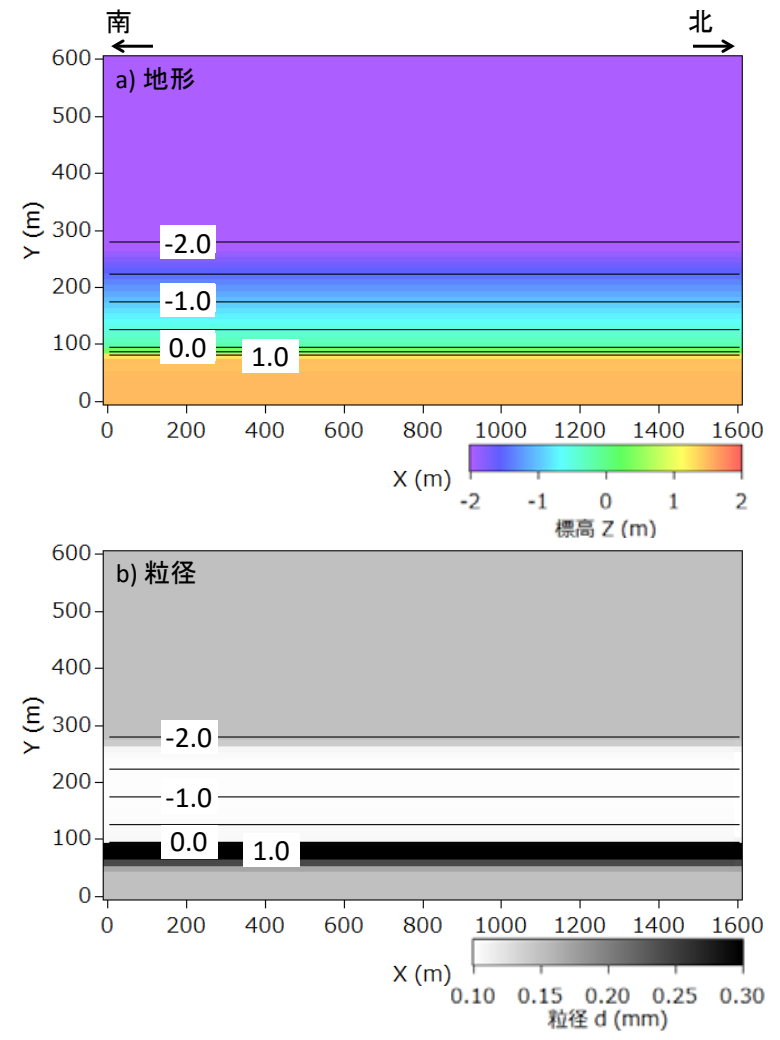

図-15初期の平面形状と粒度分布
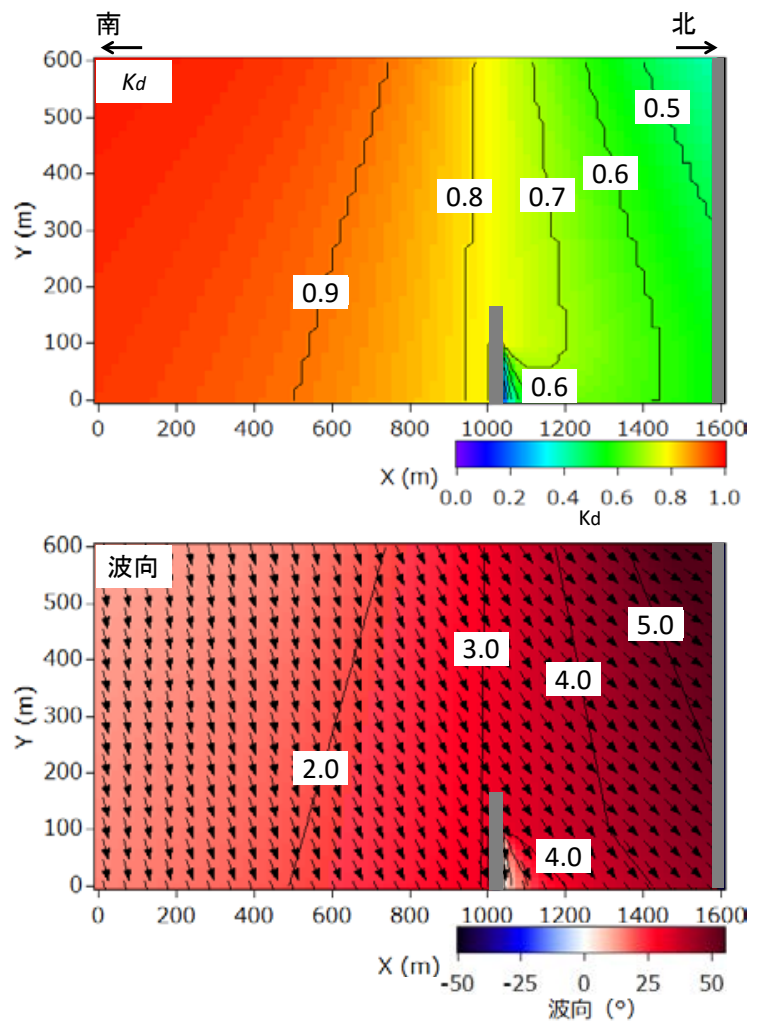

図-16 不規則波の方向分散法で求めた $K_{d}$ 值と波向の分布
表-1 計算条件

\begin{tabular}{|c|c|}
\hline 初期地形 & 平行等深線地形に波が直角入射した場合の安定地形 \\
\hline 平衡勾配 & 1/100(細砂: $0.1 \mathrm{~mm}$ ), 1/10(中砂: $0.3 \mathrm{~mm}$ ) \\
\hline 潮位条件 & M.S.L. $0.0 \mathrm{~m}$ \\
\hline 入射波条件 & 波高 $H=0.5 \mathrm{~m}$ 波向 SW \\
\hline 地形変化の水深範囲 & $\begin{array}{l}\text { バーム高 } h_{R}=1.5 \mathrm{~m} \\
\text { 波による地形変化の限界水深 } h_{C}=3 \mathrm{~m}\end{array}$ \\
\hline 境界条件 & 構造物境界: 護岸, 突堤, 防波堤 \\
\hline 漂砂量係数 & $\begin{array}{l}\text { 漂砂量係数 } A=0.3 \\
\text { 小笹·ブランプトン項の係数 } \zeta=1.62 \\
\text { 岸沖漂砂量係数 } K_{z} / K_{X}=0.1\end{array}$ \\
\hline 漂砂量の水深分布 & 一様分布 \\
\hline 土砂落ち込みの限界勾配 & 陸上 $1 / 2$, 水中 $1 / 3$ \\
\hline 計算範囲 & 沿岸方向 $X=0 \sim 1.6 \mathrm{~km}$, 岸沖方向 $Y=0 \sim 0.6 \mathrm{~km}$ \\
\hline 計算メッシュ & 沿岸方向 $\Delta X=20 \mathrm{~m}$, 岸沖方向 $\Delta Y=10 \mathrm{~m}$ \\
\hline 計算時間間隔 $\Delta t$ & $1 \mathrm{hr}$ \\
\hline 計算ステップ数 & 1 年間: 8,760 ステップ \\
\hline
\end{tabular}

が，沿岸漂砂により断面内に砂が運び込まれればこの平 坦面上での砂の堆積が起こることができる．表-1に詳細 な計算条件を示す．なお，対象海岸では潮位変動があり， 潮位変動に伴い突堤の先端水深が時間的に変わるが，本 研究では長期, 平均的な海浜変形予測を行うために潮位 変動の影響は無視した。図-15(a)はこのようにして求め た平面地形を示す.この海浜は沿岸方向に一様な縦断形 を持ち, 前浜には中砂が集中的に堆積する一方, 沖合で は細砂が勾配1/100で堆積することにより，直線的な遷 急線が形成されている，図-15(b)には対応する粒度分布 を示すが，沖浜は粒径0.1 mmの砂で構成され，前浜には 粒径0.3 mmの砂が集中的に堆積している.

次に，図-15に示す沿岸方向に一様断面を有する海浜 に対して，船形漁港の沖防波堤がある条件で不規則波の 方向分散法”を用いて入射波高，波向を $0.5 \mathrm{~m} ， \mathrm{SW}$ とえ て波浪場を計算した。図-16には不規則波の方向分散法 で求めた $K_{d}$ 值の分布と波向分布を示す。この波浪場を 与えて図-15の初期地形に対して波を1年間作用させた後 の海浜形状・粒径を図-17に示す。計算結果によれば, 突堤南側では干潟面の等深線は北向きに斜めに伸びてい るのに対し，汀線は突堤に近づくとX軸と平行となり， 干潟面の等深線と汀線が斜交している. また，防砂突堤 の北側では干潟面の等深線は防砂突堤の北側では距離と ともに大きく前進しているのに対し，汀線の前進量は小 さく，この場合も干潟面の等深線と汀線が斜交している. この結果は実測結果（図-8）をうまく説明している. 図 -17(b)に示す粒度分布の計算結果によれば, 汀線に沿っ ては中砂が帯状に堆積しているのに対し，干潟面は細砂 で覆われている。これは実測の粒度分布をうまく説明し ている. 図-18には $X=0.4 \sim 1.6 \mathrm{~km}$ での200 m間隔での縦断 形を示す. これによると $X=0.4 \sim 1.4 \mathrm{~km}$ と遷急点の標 高が高まっており, 同時に $X=1.4 \sim 1.6$ kmでは遷急線の 標高は同一の值を有する. この結果もまた, 遷急線の標 高分布（図-9）で得られた結果をうまく説明している. 

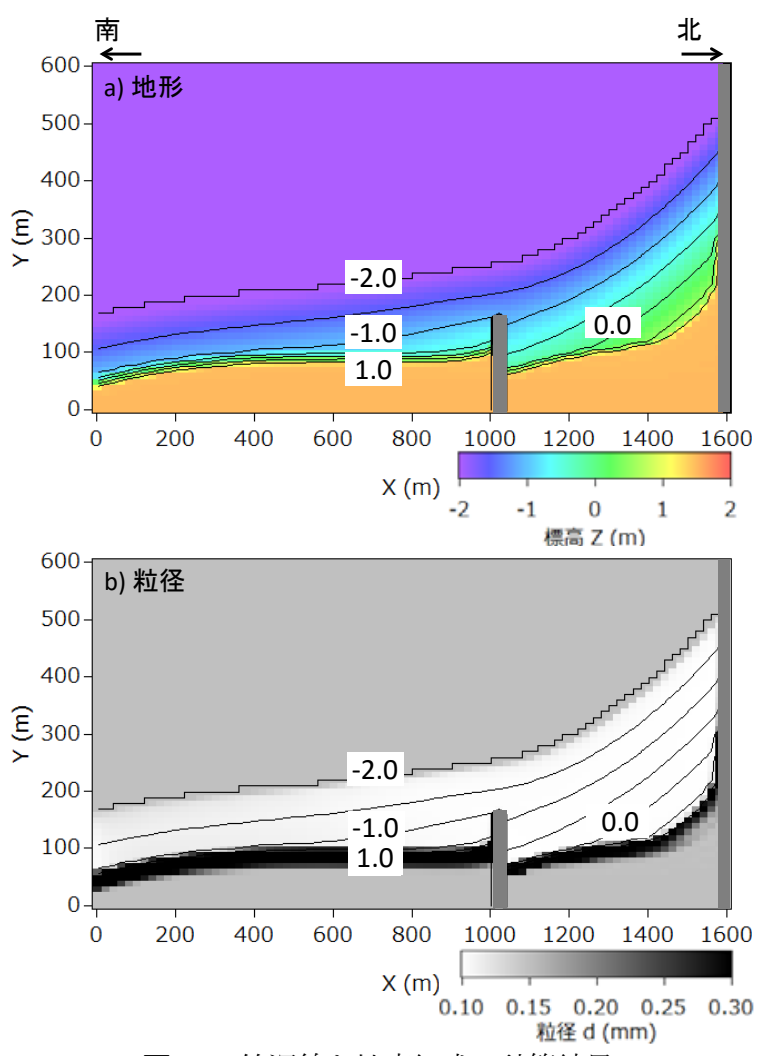

図-17 等深線と粒度組成の計算結果

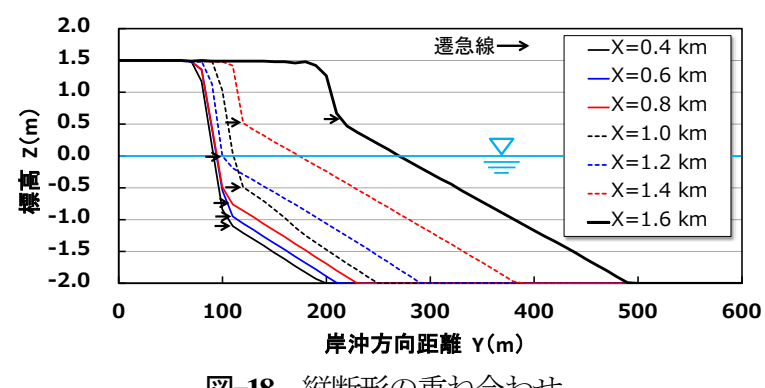

6. 結論

千葉県館山市の那古船形海岸を対象として, 砂浜と干 潟面とを分ける遷急線が汀線に対して斜交することを現 地調査により明らかにし，その上で粒度組成の変化を組

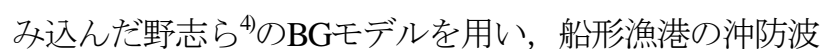
堤による波の遮蔽効果を考慮した海浜形状と粒度変化の 計算を行った．この結果，汀線と遷急線の斜交原因が， 船形漁港の沖防波堤による波の遮蔽域形成に伴う沿岸漂 砂の発達する条件下で，防砂突堤が汀線付近を集中的に 移動する粗な粒径成分の移動を阻止したのに対し，細砂 分は突堤沖を通過して北側に大量の細砂が運び込まれた ことによることが明らかになった。

\section{参考文献}

1) 宇多高明，清野聡子，足利由紀子，城野博之：高潮 に伴う中津干潟三百間地区の砂州の急変形, 海岸工 学論文集, 第 55 巻, pp.481-485, 2008.

2) 東原浩志，小林昭男，宇多高明，三上康光，野志保 仁 : 盤洲干潟縁辺部における海浜変形の現地実測, 土木学会論文集 B3（海洋開発），Vol. 71， No. 2, p.I_293-I_298, 2015.

3）宮原志帆，三波俊郎，宇多高明，芹沢真澄：干潟上 の砂州の変形・移動および海浜との融合一現地実測 と予測，土木学会論文集 B2（海岸工学）, Vol.71, No.2, pp.I_637-I_642, 2015.

4）野志保仁，小林昭男，宇多高明，熊田貴之，芹沢真 澄: 粒度組成と個々の粒径に対応した複合平衡勾配 を考慮した海浜変形・粒径変化予測モデル, 地形, Vol.29, pp.399-419, 2008.

5）菅原裕介，小林昭男，宇多高明，酒井和也，黒澤祐 司: 人為改変による砂浜消失-千葉県船形漁港周辺海 岸の例-，海洋開発論文集，第 25 巻，pp.1185-1190, 2009.

6) 姜 閏求, 高橋 重雄, 黒田 豊和, 奥平 敦彦: 前浜干潟の地形・地盤の特徵と干潟のタイプ分け人工干潟の耐波安定性に関寸る研究一, 海洋開発論 文集，第 18 巻，pp.12-18，2002.

7) 酒井和也，小林昭男，宇多高明，芹沢真澄，熊田貴 之: 波の遮蔽構造物を有する海岸における 3 次元静 的安定海浜形状の簡易予測モデル，海岸工学論文集, 第 50 巻, pp.496-500, 2003.

(2016.3.16 受付)

\section{OBLIQUE INTERSECTION OF SHORELINE WITH A LINE OF BREAK IN SLOPE BETWEEN FORESHORE AND TIDAL FLAT}

\section{Yoshiki HASHIMOTO， Akio KOBAYASHI， Takaaki UDA and Yasuhito NOSHI}

In general, foreshore and offshore tidal flat are separated with a break in slope, and a line connecting this break in slope and the shoreline obliquely intersect each other. No explanation of the mechanism was given in the previous studies. Field investigation was carried out on the Nako-funakata coast in Tateyama Bay with sandy beach and tidal flat. Also the mechanism was investigated using the BG model considering the change in grain size proposed by Noshi et al. The formation of the intersection of the shoreline with the line connecting the break in slope was explained by the difference in sand movement: coarse material was effectively blocked by a groin, whereas fine material was transported offshore of the groin by longshore sand transport which was induced by the wave-sheltering effect of the Funakata fishing port breakwater. 